\title{
ГEPMAHCbKI MOBИ
}

УДК 811.112.2’38:[81'42:004.738.5]

DOI https://doi.org/10.32838/2710-4656/2021.5-1/15

Авчіннікова Г.Д.

Уманський державний педагогічний університет імені Павла Тичини

\section{ЛІНГВОСТИЛІСТИЧНІ ОСОБЛИВОСТІ НІМЕЦЬКОМОВНОГО ІНТЕРНЕТ-ДИСКУРСУ}

У статті проаналізовано поняття «комунікаиія» та «Інтернет-комунікація», розглянуто специфіку Інтернету як засобу комунікації, який визначає типи Інтернет-комунікаиії. Актуальність теми зумовлена інтересом сучасної лінгвістики до питань розвитку мови, що, зокрема, пояснюється тією значною і неухильно зростаючою роллю, яку відіграють слова й терміни з області Інтернет-комунікачії в різних областях мовної діяльності, а також відсутністю трунтовного дослідження лінгвостилістичних особливостей німецьвкоовного Інтернет-дискурсу.

Основними иілями дослідження було визначено розгляд поняття «комунікація》, особливостей ї̈ вербального та невербального аспектів, ролі мови як засобу комунікачії, а також вияв специфіки Інтернет-комунікації, щуо розуміється як міжособистісна комунікація, опосередкована комп 'ютером через мережу Інтернет.

У статті визначено Інтернет-комунікацію як комунікацію, здійснювану між людьми за допомогою мережі Інтернет та охарактеризовано трьома функиіями: функиія економії мовних засобів; функиія ідентифікації; функиія інтерпретації. 3'ясовано відмінності між синхронною та асинхронною комунікацією.

Аналіз теоретичного матеріалу дав змогу визначити комунікацію як взаємний прочес, що відбувається між двома або більме учасниками комунікачії, з метою отримання інформачії, обміну досвідом, враженнями, думками. Характерними особливостями Інтернет-комунікаиї є відсутність особливостей, властивих природній комунікаиії, наприклад, відсутність змоги скористатися жестами та мімікою, або потреба чітко й лаконічно формувати думки.

Встановлено, щуо більшості типів Інтернет-комунікаиії властиві відсутність безпосереднього зворотного зв'язку, можливість ведення комунікаиї̈ між двома чи більшою кількістю учасників, ї̈ сленговий характер.

Також у дослідженні з'ясовано компоненти, форми та функиії комунікащії. Автором досліджено метафори, які використовуються в цій сфері комунікаиї̈, і правила мережевого етикету.

Ключові слова: Інтернет-комунікація, німеиька мова, лінгвостилістичні особливості, метафора, типи комунікації.

Постановка проблеми. У наш час лінгвістами багатьох країн визначається надзвичайна активізація в еволюції мов різного типу. Це пов'язано, в першу чергу, з науково-технічним прогресом, який торкнувся майже всіх країн земної кулі, серйозними політичними та соціальними змінами, розвитком засобів масової комунікації. Інтернет є одним із найбільших технологічних феноменів у сучасній історії. Нині він $є$ тим засобом комунікації, який розвивається найстрімкіше. Це зумовлено високою швидкістю передачі даних практично в будьяку точку земної кулі й зручністю використання.
Спілкування в мережі Інтернет передбачає специфічні форми комунікації. Ця комунікація здебільшого характеризується відсутністю безпосереднього контакту між користувачами, що вимагає застосування спеціальних засобів вираження. При цьому мова залишається найважливішим засобом комунікації в Інтернеті, а в умовах спілкування людей за допомогою мережі Інтернет у мові розвиваються специфічні форми вираження змісту повідомлення та емоцій комунікантів. Актуальність теми зумовлена інтересом сучасної лінгвістики до питань розвитку мови. 
У лінгвістичній літературі дедалі більше уваги приділяється проблемі взаємодії літературної мови, спеціальних мов і жаргонів. Це пояснюється тією значною і неухильно зростаючою роллю, яку відіграють слова й терміни $з$ області Інтернеткомунікації в різних областях мовної діяльності.

Аналіз останніх досліджень і публікацій. Комунікація - дуже складний феномен. Дослідники з різних областей науки наводять різні визначення. Ми розглянемо деякі з них. Наприклад такі дослідники, як Р. Портер і Л. Самовар, визначають комунікацію як «те, що відбувається щоразу, коли хтось реагує на поведінку або наслідки поведінки іншої людини» [1]. І. Яковлєв, досліджуючи комунікацію, концентрує увагу на їі ролі в суспільстві, маючи на увазі їі розвиток, зміст і структуру комунікаційних процесів, використання їх ресурсів. М. Андріанов у процесі дослідження комунікації ставить на чільне місце сенс аспектів соціальної взаємодії [3, с. 8-10].

На думку дослідника С. Боріснева, комунікацією є соціально зумовлений процес передачі та сприйняття інформації в умовах міжособистісного й масового спілкування по різних каналах за допомогою різних засобів комунікації [1]. Виникає питання: чи обов'язково учасниками комунікації мають бути люди або живі істоти, чи можна вважати різні технічні пристрої учасниками комунікації? Наприклад, спілкування «людинакомп’ютер» теж можна зарахувати до комунікації, бо метою будь-якої комунікації є розуміння.

Нині немає єдиного визначення Інтернет-комунікації. Такі автори, як Л. Щіпіціна і I. Розіна, називають їі комп'ютерно опосередкованою комунікацією, О. Лутовинова і Л. Компанцева визначають як віртуальний дискурс [2, с. 114]. Деякими лінгвістами Інтернет-комунікація визначається як електронне спілкування або комунікація. Інтернет-комунікація, будучи комунікацією, не має при цьому деяких особливостей, властивих реальній комунікації, таких як жести, вирази обличчя, інтонація і тон, а також безпосередній зворотний зв'язок. Незважаючи на наявність зазначених досліджень, вони не розкривають лінгвостилістичних особливостей німецькомовного Інтернет-дискурсу.

Постановка завдання. Предметом дослідження цієї статті $є$ розгляд мовностилістичних особливостей німецькомовних текстів Інтернеткомунікації. Елемент наукової новизни полягає в спробі виявлення одиниць, що належать до новітнього пласту комп'ютерної та мережевої лексики в сучасній німецькій мові, а також у спробі їх систематизації.
Метою є аналіз мовних особливостей Інтернеткомунікації німецькою мовою. Для досягнення вказаної мети ставляться такі завдання (цілі):

- розгляд поняття «комунікація», особливостей ії вербального та невербального аспектів, ролі мови як засобу комунікації;

- вияв специфіки Інтернет-комунікації, що розуміється як міжособистісна комунікація, опосередкована комп'ютером через мережу Інтернет;

- вияв типів Інтернет-комунікації та розгляд умов їх здійснення, релевантних для вибору мовних засобів;

- визначення місця засобів вираження, властивих Інтернет-комунікації, в системі німецької мови;

- вияв особливостей лексики, характерної для німецькомовної Інтернет-комунікації, і класифікація цієї лексики.

У процесі роботи застосовувалися такі методи збору матеріалу та дослідження: метод суцільної вибірки, порівняльний аналіз, компонентний аналіз, семантичний аналіз.

Джерелами матеріалу є німецькомовні вебсайти ChatCity, Musiker-Board, Newsgroups, a також німецькомовні словники комп'ютерної та мережевої термінології, розміщені у вільному доступі в мережі Інтернет.

Виклад основного матеріалу. Ключовим для нашого дослідження є поняття комунікації. Слово «комунікація» походить від латинського дієслова «communicare», який перекладається як «ділити, розділяти, брати участь, робити разом, спілкуватися». Комунікацією є обмін або передача інформації. У цьому контексті під словом «інформація» варто розуміти знання або досвід, отже, обмін інформацією є обміном думками, уявленнями, поглядами та досвідом між комунікантами.

Комунікація розглядається як взаємний процес, під час якого обидва комуніканти мають активно брати участь у ньому. Необхідною умовою для успішної реалізації комунікації $є$ здатність усіх учасників комунікаційного процесу розуміти один одного, наприклад, комуніканти мають розмовляти однією мовою або мати досить спеціальних знань у певній галузі для успішного спілкування.

Для здійснення комунікації, що складається 3 кодування інформації, передачі інформації та іiі розшифрування, мають бути присутніми такі компоненти:

- відправник інформації (один із комунікантів або джерело інформації);

- інформація (повідомлення, публікація);

- засіб комунікації (наприклад технічні засоби);

- одержувач інформації [10]. 
Серед форм комунікації виділяють дві: одностороння комунікація та багатостороння комунікація. До односторонньої належать промови, виступи, доповіді, реферати, спічі, висловлення власної думки, інші види монологічного мовлення. До багатосторонньої своєю чергою належать розмови, обговорення, інтерв'ю, дебати, переговори, інші види діалогічного мовлення чи спілкування трьох і більше людей. Форми комунікації також діляться на індивідуальну, міжособистісну, групову та масову.

Думки не можуть бути передані іншій людині без особливих засобів, тому виникає необхідність використання сигналів і символів як засобів комунікації. Вони можуть бути вербальними та невербальними. Основним типом комунікації $є$ вербальна-вонауніверсальна. До цього типу належать усна й письмова мова. Під вербальною комунікацією розуміється будь-яка форма міжособистісної комунікації за допомогою мови. Сюди можна зарахувати як усну, так і письмову комунікацію.

До невербальної комунікації зараховуємо систему жестів, міміку, зоровий контакт між комунікантами, знаки, символи, зовнішній вигляд такої мови, як азбука Морзе, мови програмування, ноти тощо. Головні функції невербальної комунікації:

- доповнення та заміщення мовного висловлювання;

- регуляція міжособистісних відносин;

- репрезентація емоційних станів;

- обмін ритуалами тощо [11].

Розглянувши різні трактування поняття «комунікація», мидійшливисновку,щозагальнимдляних $\epsilon$ обмін і передача інформації між комунікантами різними способами. У межах нашого дослідження під комунікацією розуміємо обмін інформацією, здійснюваний вербально або невербально індивідами за допомогою загальної системи символів.

Нині Інтернет набув поширення по всьому світу, він є найбільш доступним, оперативним i повним джерелом інформації, а також засобом комунікації. Далі детальніше проаналізуємо Інтернет як засіб комунікації.

Інтернет (від латинського «inter» - між та «net» - мережа) - всесвітнє об'єднання обчислювальних і автономних систем. Культурне значення розвитку Інтернету порівнюють із винаходом друкарства. У наш час він став невід'ємною частиною повсякденного життя. Тому окреслимо характеристики всесвітньої мережі, які визначають особливості Інтернет-комунікації:

- постійна доступність інформації. Можна за секунди отримати доступ до всіх даних, що зна- ходяться в Інтернеті, в будь-який час і практично з будь-якої країни світу;

- інтерактивність. Змінність ролі відправника та одержувача (як у спілкуванні через електронну пошту) говорить про інтерактивність між комунікантами; користувачі взаємодіють і можуть як приймати, так і відхиляти передану інформацію;

- пряма адресація інформації. Незалежно від різниці в часі та великої відстані, Інтернет дає змогу здійснювати прямий зв'язок між двома або більше співрозмовниками;

- індивідуальність. Користувач добирає інформацію на основі власних потреб та уподобань [6].

Зазначені характеристики визначають особливості Інтернет-комунікації, про що йдеться далі в нашому дослідженні. Поняття «Інтернеткомунікація» багатозначне, воно може означати міжособистісну комунікацію, опосередковану комп'ютером через мережу Інтернет, або зв'язок комп'ютерів за допомогою мережі.

Під Інтернет-комунікацією розуміємо комунікацію, здійснювану між людьми за допомогою мережі Інтернет. Інтернет-опосередкована комунікація може бути міжособистісною або масовою залежно від кількості людей, які беруть у ній участь.

Крім того, Інтернет-комунікацію можна охарактеризувати трьома функціями:

1) функція економії мовних засобів - економія часу та зусиль шляхом скорочення слів і виразів;

2) функція ідентифікації - використання специфічних символів, виразів і термінів;

3) функція інтерпретації - через використання розмовних виразів, помилок і характерних знаків передається інформація про партнера і те, як слід інтерпретувати те, що було написано партнером $[9$, c. 36].

Для компенсації труднощів, які виникають через неможливість повною мірою проявляти емоції в Інтернет-опосередкованій комунікації, в Інтернеті $є$ спеціальні прийоми.

Інтернет-комунікації притаманні такі ознаки:

- антропоцентричність;

- приналежність до соціальної діяльності;

- діалогічность;

- особливий характер авторства;

- наявність категорії авторизації з чітко вираженим суб'єктом;

- особливе уявлення про об'єкт зображення;

- зняття тимчасових і просторових обмежень;

- наголошення на рівноправність учасників;

- необмеженість у виборі мовних засобів $[3$, c. 43$]$. 
Спілкування в мережі Інтернет передбачає специфічні форми комунікації. Комунікація може ділиться на синхронну та асинхронну.

Наприклад, так звана електронна пошта являє собою асинхронний вид комунікації, в якому електронні повідомлення, спрямовані певному адресату, можуть бути прочитані, оброблені, збережені або переслані далі. Йдеться про форму спілкування, в якій відправник та отримувач інформації не перебувають у мережі одночасно. Прикладом служать SMS-повідомлення, повідомлення у Viber, Messenger, Instagram тощо, а також повідомлення в групах обговорення [7].

До другого виду комунікації належить синхронна комунікація, реалізація якої відбувається в режимі реального часу. Партнери по комунікації одночасно відправляють або отримують дані, тобто під час виклику або написання повідомлення користувачі активні, і під час звернення можуть негайно обробити отриману інформацію. До прикладів такого виду комунікації належать чати, Інтернетдзвінки або онлайн-ігри. За деякими винятками (відеоконференції за допомогою GoogleMeet, Skype) Інтернет-комунікація проходить без таких вербальних і невербальних засобів спілкування, як жести, міміка, інтонація тощо [4, с. 107].

Користувач, сидячи за комп'ютером, практично не рухається, адже для того, щоб стежити за швидко мінливим змістом розмови, потрібна концентрація уваги. Під час такої комунікації не вдається продемонструвати жести, міміку або, наприклад, відвернутися від співрозмовника через роздратування, виразити нерозуміння або скептичне ставлення до слів партнера по комунікації чи то знизування плечима на знак невпевненості. Це іноді призводить до нерозуміння. Всі емоції мають бути передані лише за допомогою клавіатури. 3 цього виникає необхідність правильно складати повідомлення для партнерів по комунікації. Коли під час комунікації в повідомленнях дотримана тактовність, то спілкування проходить легко та без непорозумінь.

Розглядаючи детально спілкування в Інтернеті, не можемо не згадати про метафору. Метафора -це вираз, який передає не буквальне значення фрази або слова, а переносне. Метафори, як правило, вживаються в художній літературі для більш яскравого опису того, що відбувається. Відмінною рисою метафори $є$ аналогія між буквальною фразою та ії̈ смислом. Існує кілька типів метафор:

1) персоніфіковані - це метафори, які надають неживим предметам людські риси (наприклад «Die Wolken weinen» (хмари плачуть));
2) стерта метафора - метафора, сенс якої вже не є відомим;

3) розгорнута метафора - метафора, що складається з різних схожих асоціацій;

4) стійка метафора - метафора, сенс якої залишається незмінним у будь-якому контексті.

Метафори широко вживаються не лише в літературі та публіцистиці, а найпоширенішими метафорами, що стосуються Інтернету та Інтернет-комунікації німецькою мовою, є такі слова, як «global Net» (глобальна павутина), «elektronisches Netz» (електронна мережа), «Cyberspace» (віртуальний простір), «Troll» (троль, провокація в Інтернеті), «Navigation» (навігація), «Datenmeer» (море даних), «Trojanisches Pferd» (троянський кінь (позначення для вірусу)). Метафоричність $\epsilon$ важливою особливістю Інтернет-комунікації [6].

Особливості мови, які проявляються у спілкуванні в мережі Інтернет, позначаються терміном «мережевий жаргон». Аналіз мовного матеріалу показав, що до особливостей лексики німецькомовної Інтернет-комунікації належать термінологічний характер, запозичення і словоскладання.

Таким чином, Інтернет-комунікація $є$ фактором збагачення словникового складу німецької мови. Запозичення з англійської мови є суттєвою особливістю німецькомовної Інтернет-комунікаціï, при цьому вони служать матеріалом для створення нових слів за правилами німецького словотворення Chatsprache, anklicken, klickbar.

У результаті аналізу матеріалів Інтернет-джерел було виявлено значну кількість скорочень. Скорочення при Інтернет-комунікації, як правило, використовуються задля передачі якомога більшої кількості інформації за короткий час. Аналіз їх структури дозволив встановити, що більшість скорочень $\epsilon$ абревіатурами. Було встановлено, що до важливих функцій скорочень, що використовуються в дистанційному письмовому спілкуванні, належить не тільки мовна економія, але й висловлення емоцій партнерів по комунікації.

До орфографічних і графічних особливостей німецькомовної Інтернет-комунікації належить використання так званого «Leetspeak» i різних емотіконів. Leetspeak - це заміна букв зображеннями за допомогою цифр, що дає змогу автору повідомлення відокремитися від інших (недосвідчених) користувачів Інтернету [7]. Емотікони широко використовуються для вираження емоцій. Крім того, щоб представити себе, виділитися серед інших або підкреслити своє ставлення, можлива зміна кольору шрифту, його форми, розміру 
і положення. На німецькомовних форумах і в чаткімнатах також часто зустрічається написання всього тексту повідомлення малими літерами, без дотримання правил німецької орфографії.

Висновки і пропозиції. Нині Інтернет - найбільш доступне, оперативне й повне джерело інформації, а також засіб комунікації. Як засіб комунікації Інтернет поширюється найшвидше, такі його характеристики, як постійна доступність, пряма адресація інформації, інтерактивність, індивідуальність, визначають особливості спілкування в мережі. Під Інтернет-комунікацією ми розуміємо опосередковану мережею Інтернет міжособистісну комунікацію за допомогою різних технічних пристроїв. Така комунікація $\epsilon$ переважно вербальною і має текстову форму.

Аналіз теоретичного матеріалу дозволив нам визначити комунікацію як взаємний процес, що відбувається між двома або більше учасниками комунікації, 3 метою отримання інформації, обміну досвідом, враженнями, думками. Мова $€$ найважливішим засобом комунікації, в тому числі в Інтернеті. Нами визначені характерні особливості Інтернет-комунікації: відсутність осо- бливостей, властивих природній комунікації, наприклад, відсутність можливості скористатися жестами та мімікою, або потреба чітко й лаконічно формувати думки.

Вивчення теоретичної літератури дозволило нам встановити, що більшості типів Інтернеткомунікації властиві відсутність безпосереднього зворотного зв'язку, можливість ведення комунікації між двома чи більшою кількістю учасників, іiі сленговий характер.

Важливою особливістю Інтернет-комунікації $\epsilon$ метафоричність. Метафори поширені як у професійному комп'ютерному жаргоні, так і в повсякденному непрофесійному спілкуванні в мережі Інтернет. Комп'ютерна та Інтернет-термінологія використовується не тільки в рамках Інтернеткомунікації, але активно проникає в молодіжний сленг і розмовну мову.

На нашу думку, цікавими будуть подальші дослідження німецькомовного Інтернет-дискурсу, зокрема, вивчення впливу локдауну та дистанційності на зміну кількості користувачів Інтернету, проведеному часу онлайн, кількості сайтів та їх змісту від початку пандемії.

\section{Список літератури:}

1. Асмус Н. Г. Лингвистические особенности виртуального коммуникативного пространства : дис. ... канд. філол. наук : 10.02.19/ Челябинск, 2005. 265 c. URL: http://www.lib.csu.ru/texts/diss/002689.pdf (дата обращения: 10.08.21).

2. Пескова Е. Н. Дискурс веб-сайта: взаимодействие с другими типами дискурса, жанровые особенности. Учёные записки ЗабГУ. Филология, история, востоковедение. 2015. № 2 (61). С. 112-116.

3. Чащин О. А. Лингвостилистические особенности немецкоязычных текстов интернет-коммуникации. Иркутск, 2013. 72 c. URL: https://www.docme.su/doc/1186604/3421.lingvostilisticheskie-osobennostinemeckoyazychnyh-tekstov (дата обращения: 12.08.2021).

4. Шевченко І. С. Когнітивно-прагматичні дослідження дискурсу. Дискурс як когнітивно-комунікативний феномен : кол. монографія / під заг. ред. І. С. Шевченко. Харків: Константа, 2005. С. 105-117.

5. Bußman H. Lexikon der Sprachwissenschaft 3. Kröner, Stuttgart, 2002. 131 S.

6. Döring, N. Identität und Internet = Virtuelle Identität? Forum Medienethik. Kopaed Verlags GmbH. München, 2000. S. 65-75.

7. Döring N. Sozialpsychologie des Internet. Göttingen.: Hogrefe Verlag, 2003. 56 S.

8. Kluver R. Globalization, Informatization, and Intercultural Communication. American Communication Journal. Vol. 3. Issue 3. May 2000. URL: http://www.acjournal.org/holdings/vol3/Iss3/spec1/kluver.htm.

9. Arntz R., Picht H., Mayer F. Einführung in die Terminologiearbeit, 5. Auflage. Georg Olms Verlag, 2004. $112 \mathrm{~S}$.

10. Siever T., Schlobinski P., Runkehl J. Websprache.net. Sprache und Kommunikation im Internet. B.: [s.n.], 2005. $49 \mathrm{~S}$.

11. Voigt S. E-Mail-Kommunikation in Organisationen. Eine explorative Studie zu individuellen Nutzungsstrategien. Internet Research. Bd. 11. München, 2007. 73 S. 


\section{Avchinnikova H. D. LANGUAGE AND STYLISTIC FEATURES OF THE GERMAN LANGUAGE INTERNET DISCOURSE}

The article analyzes the concepts of "communication" and "Internet communication", considers the specifics of the Internet as a means of communication that determines the types of Internet communication. The urgency of the topic is due to the interest of modern linguistics in language development, which, in particular, is due to the significant and steadily growing role played by words and terms in the field of Internet communication in various fields of language, and lack of thorough study of linguistic stylistic features of German-language Internet.

The main objectives of the study were to consider the concept of "communication", features of its verbal and nonverbal aspects, the role of language as a means of communication, as well as the manifestation of the specifics of Internet communication, understood as interpersonal communication mediated by a computer via the Internet.

The article defines Internet communication as communication between people via the Internet and describes three functions: the function of saving language resources; identification function; interpretation function. The differences between synchronous and asynchronous communication are clarified.

The analysis of theoretical material allowed to define communication as a mutual process that takes place between two or more participants in communication, in order to obtain information, exchange experiences, impressions, thoughts. Characteristic features of Internet communication are the lack of features inherent in natural communication, such as the inability to use gestures and facial expressions, or the need to clearly and concisely form ideas.

It is stated that for most types of Internet communication is characterized by the lack of direct feedback, the ability to communicate between two or more participants, its slang nature.

The study also clarifies the components, forms and functions of communication. The author explores the metaphors used in this area of communication and the rules of network etiquette.

Key words: Internet communication, German language, linguistic and stylistic features, metaphor, types of communication. 